\title{
Filaggrin loss-of-function mutations as a predictor for atopic eczema, allergic sensitization and eczema-associated asthma in Polish children population
}

\author{
Anna Dębińska ${ }^{A-E}$, Hanna Danielewicz ${ }^{A-C, E}$, Anna Drabik-Chamerska ${ }^{B, C}$, Danuta Kalita ${ }^{B, C}$, Andrzej Boznański ${ }^{A, E, F}$ \\ $1^{\text {st }}$ Department and Clinic of Pediatrics, Allergology and Cardiology, Wroclaw Medical University, Poland \\ A - research concept and design; $\mathrm{B}$ - collection and/or assembly of data; $\mathrm{C}$ - data analysis and interpretation; \\ $D$ - writing the article; $E$ - critical revision of the article; $F$ - final approval of article
}

\section{Address for correspondence}

Anna Dębińnka

E-mail:anna.debinska@umed.wroc.pl

Funding sources

None declared

Conflict of interest

None declared

Received on 0ctober 20, 2015

Revised on December 3, 2015

Accepted on January 19, 2016

DOI

$10.17219 /$ acem $/ 61430$

\section{Copyright}

Copyright by Author(s)

This is an article distributed under the terms of the

Creative Commons Attribution Non-Commercial License

(http://creativecommons.org/licenses/by-nc-nd/4.0/)

\begin{abstract}
Background. Loss-of-function mutations in the filaggrin ( $F L G)$ gene were identified as a major risk factor for atopic eczema.

Objectives. The aim of the study was to investigate the importance of 4 common FLG null mutations in the susceptibility to atopic eczema and other allergic phenotypes in Polish children population.

Material and methods. The FLG mutations were determined in 158 children younger than 2 years of age. All subjects were selected using a detailed questionnaire and blood samples for total and specific lgE measurements were obtained. Cases of atopic eczema were diagnosed according to the criteria of Hanifin and Rajka and skin examination. All FLG mutations were genotyped by real-time PCR assays with a subsequent melting curve analysis using a SimpleProbe ${ }^{\circledR}$ probes.

Results. The combined genotype of all 4 mutations (carriage of $\geq 1$ FLG mutation) was significantly associated with atopic eczema $(p=0.016)$. The odds ratio (OR) for individuals carrying 1 of these 4 null mutations was 5.52 (95\% Cl; $1.11 \div 37.12)$. The significant association between either the combined FLG genotype or 2282del14 deletion and eczema was seen only in the allergic group. The association with asthma was restricted to asthma occurring in the context of eczema $(0 \mathrm{R}, 6.27 ; 95 \% \mathrm{Cl}, 0.89 \div 53.56 ; \mathrm{p}=0.042)$.

Conclusions. Our study confirms the previous findings that $F L G$ mutations are strongly associated with atopic eczema and confer a significant risk of allergic sensitization and asthma in the context of eczema. These results underline the role of the epidermal barrier and filaggrin insufficiency in the pathogenesis of atopic eczema and eczema-associated asthma.
\end{abstract}

Key words: asthma, atopic dermatitis, atopic eczema, genotype, mutation 
Atopic eczema (or atopic dermatitis) is a chronic inflammatory skin disease with the onset typically occurring in early childhood and is the most common chronic inflammatory skin disease affecting children in the industrialized country. The worldwide cumulative prevalence of atopic eczema is approx. 10-20\% in this age group with a steady increase over the past decades. Around $50 \%$ of the cases are diagnosed by the age of 1 year, with $1 / 3$ of patients having disease persists throughout adulthood. ${ }^{1}$ A multifactorial background for atopic eczema has been suggested with genetic as well as well environmental factors influencing disease development. Atopic eczema is associated with a number of abnormalities in skin barrier function owing to the mutations in cornified envelope genes, reduced ceramide levels, increased levels of endogenous proteolytic enzymes and enhanced transepidermal water loss. ${ }^{2}$ Several recent studies have shown that the loss-of-function mutations of the epidermal barrier protein filaggrin are a major predisposing factor for atopic eczema. ${ }^{3-5}$ The filaggrin gene is found on chromosome 1q21 which also contains genes of the epidermal differentiation complex that are expressed during the terminal differentiation of the epidermis. ${ }^{6}$ Filaggrin deficiency has been shown experimentally to lead to the failure of the barrier function of the skin in humans. ${ }^{7}$ An impressive series of replication studies that have followed the initial publication from Palmmer et al. ${ }^{3}$ showed FLG to be the gene with the most widely replicated association with atopic eczema. ${ }^{4,8,9}$ An association with asthma was also suggested and confirmed in subsequent reports on asthma occurring in association with eczema. ${ }^{3,8-13}$ However, these studies exhibited considerable heterogeneity concerning the study design and magnitude of the genetic effect.

In the current study, we aimed to assess the importance of filaggrin loss-of-function mutations in the susceptibility to atopic eczema and disease severity in Polish children younger than 2 years of age. Moreover, we evaluated the association of the FLG mutations with other atopic phenotypes, such as eczema-associated asthma and allergic sensitization.

\section{Material and methods}

\section{Study population}

A total of 158 unrelated children (94 males) younger than 2 years at the time of recruitment were enrolled and followed at yearly intervals thereafter until age 4 years. The study subjects were recruited from the general population. All study participants were of Caucasian ethnicity. All subjects were selected using a detailed questionnaire that included questions on symptoms of eczema and asthma, sociodemographic information and family history of allergic diseases. The diagnosis of eczema was made according to the criteria of Hanifin and Rajka and visible symptoms of disease at the time of recruitment and follow-up. ${ }^{14}$ Disease severity was assessed by using the SCORing Atopic Dermatitis index (SCORAD) and the patients were divided into mild ( $<15$ points), moderate (15-40 points) or sever ( $>40$ points) disease groups. The subjects with eczema were divided into atopic and non-atopic on the basis of the presence of allergic sensitization. Asthma was defined by the presence of 1 or more wheezing episodes during the previous 12 months at the age 3 or/and 4 years or a physician's diagnosis of asthma by 4 years of age. The control subjects met the following criteria: absence of symptoms of atopic eczema and asthma and negative family history of allergic diseases.

In all recruited subjects, serum measurements for total and specific IgE levels were performed, including IgE specific for inhalant mix (Dermatophagoides pteronyssinus, Dermatophagoides farina, cat, dog and horse epithelia, birch pollen, Timothy grass pollen, mugwort pollen, Aspergillus fumigatus, Cladosporium herbarum) and food mix (peanut, milk, egg white, egg yolk, potato, carrot, cod, apple, soya, wheat flour). The concentration of total serum IgE was measured by using a commercially available kit IMMULITE 2000 Total IgE (Diagnostic Products Corporation (DPC), USA). The levels of specific IgE were determined using a standard enzyme immunoassay (Polycheck, BIOCHECH, Germany). Allergic sensitization was defined as the presence of specific IgE level of $\geq 0.7 \mathrm{kU} / \mathrm{L}$ (class II) or greater to at least 1 tested allergen.

The study was approved by the ethics committee, and an informed written consent, including consent for genetic studies, was obtained from all of the subjects before testing.

\section{Genotyping}

The samples of the 158 subjects were genotyped for the FLG mutations R501X, 2282del4, R2447X and S3247X. Children with a mutation in any of these positions were classified as a loss-of-function mutation. Genomic DNA was obtained from EDTA whole blood samples using the QIAamp DNA Blood Mini Kit (QIAGEN GmbH, Germany). All mutations were determined using LightSNiP assay (TibMolbiol, Berlin, Germany). PCR was performed in a final volume of $10 \mu \mathrm{L}$ containing $1 \mu \mathrm{L}$ of DNA at a concentration of $15-60 \mathrm{ng} / \mu \mathrm{L}, 0.5 \mu \mathrm{L}$ of reagent mix containing specific primers and SimpleProbes ${ }^{\circledR}$ probes at optimized concentrations, $0.8 \mu \mathrm{L}$ of $\mathrm{MgCl} 2$ and $1 \mu \mathrm{L}$ of LightCycler ${ }^{\circledR}$ FastStart DNA MasterHybProbe (Roche Applied Science, Mannheim, Germany). Reactions were performed on a Light Cycler 1.5 platform (Roche Applied Science, Mannheim, Germany). For quality control of genotyping procedures, positive controls of each genotype, as well as negative controls, were included in each reaction. 


\section{Statistical analysis methods}

The Hardy-Weinberg equilibrium was tested using the $\mathrm{X}^{2}$ goodness-of-fit test to compare the observed genotype frequencies with the expected frequencies among the controls. Differences in genotype frequencies or demo-

Table 1. Characteristics of the study group. Polisensitization: The presence of specific lgE level of $\geq 0,7 \mathrm{kU} / \mathrm{L}$ (class II) or greater to more than 1 tested allergen

\begin{tabular}{|c|c|c|}
\hline Variable & $\begin{array}{c}\text { Eczema } \\
n=87\end{array}$ & $\begin{array}{l}\text { Control } \\
n=71\end{array}$ \\
\hline $\begin{array}{l}\text { Age: month } \\
(\text { mean } \pm \text { SD) }\end{array}$ & $13.2 \pm 6.7$ & $15.3 \pm 5.6$ \\
\hline $\begin{array}{l}\text { Gender } \\
\text { (male/female) }\end{array}$ & $56 / 31$ & $38 / 33$ \\
\hline Allergic sensitization (\%) & $42(48.3 \%)$ & $8(11.3 \%)$ \\
\hline Asthma (\%) & $26(29.9 \%)$ & 0 \\
\hline $\begin{array}{l}\text { SCORAD } \\
\text { mild } \\
\text { moderate } \\
\text { sever }\end{array}$ & $\begin{array}{c}54(62 \%) \\
33(38 \%) \\
0\end{array}$ & $\begin{array}{l}0 \\
0 \\
0\end{array}$ \\
\hline Polisensitization (\%) & $23(26.4 \%)$ & 0 \\
\hline Atopic hereditary (\%) & $49(56 \%)$ & 0 \\
\hline $\begin{array}{l}\text { Serum total lgE IU/mL } \\
\text { geometric mean } 95 \% \mathrm{Cl}\end{array}$ & $\begin{array}{c}26.68 \\
(12.72 \div 40.63)\end{array}$ & $\begin{array}{c}14.99 \\
(11.15 \div 18.83)\end{array}$ \\
\hline
\end{tabular}

Table2. Frequencies of FLG mutations and the combined FLG genotype in eczema cases and controls

\begin{tabular}{|c|c|c|c|c|}
\hline \multirow{2}{*}{ Genotype } & \multirow{2}{*}{$\begin{array}{c}\text { Control } \\
\mathrm{n}(\%)\end{array}$} & \multicolumn{3}{|c|}{ Eczema } \\
\hline & & $n(\%)$ & $\mathrm{p}$-value & OR $(95 \% \mathrm{Cl})$ \\
\hline $\begin{array}{l}\text { R501X } \\
\text { normal } \\
\text { null }\end{array}$ & $\begin{array}{c}70(98.6 \%) \\
1(1.4 \%)\end{array}$ & $\begin{array}{c}86(98.8 \%) \\
1(1.2 \%)\end{array}$ & $p=0.888$ & $1.22(0.03 \div 45.8)$ \\
\hline $\begin{array}{l}\text { 2282del14 } \\
\text { normal } \\
\text { null }\end{array}$ & $\begin{array}{c}70(98.6 \%) \\
1(1.4 \%)\end{array}$ & $\begin{array}{c}80 \text { (92.0\%) } \\
7(8.0 \%)\end{array}$ & $p=0.058$ & $6.12(0.72 \div 135.7)$ \\
\hline $\begin{array}{l}\text { R2447X } \\
\text { normal } \\
\text { null }\end{array}$ & $\begin{array}{c}71(100 \%) \\
0\end{array}$ & $\begin{array}{c}86 \text { (98.8\%) } \\
1(1.2 \%)\end{array}$ & $p=0.365$ & - \\
\hline $\begin{array}{l}\text { S3247X } \\
\text { normal } \\
\text { null }\end{array}$ & $\begin{array}{c}71(100 \%) \\
0\end{array}$ & $\begin{array}{c}84(96.6 \%) \\
3(3.4 \%)\end{array}$ & $p=0.114$ & - \\
\hline $\begin{array}{l}\text { Combined FLG genotype } \\
\text { normal } \\
\text { null }\end{array}$ & $\begin{array}{c}69(97.2 \%) \\
2(2.8 \%)\end{array}$ & $\begin{array}{c}75(86.2 \%) \\
12(13.8 \%)\end{array}$ & $p=0.016$ & $5.52(1.11 \div 37.12)$ \\
\hline
\end{tabular}

Table 3. Associations between FLG mutation 2282del14 and the combined FLG genotype and eczema severity

\begin{tabular}{|l|c|c|c|c|}
\hline \multicolumn{1}{|c|}{ Genotype } & $\begin{array}{c}\text { Mild eczema } \\
\mathrm{n}(\%)\end{array}$ & $\begin{array}{c}\text { Moderate } \\
\text { eczema } \mathrm{n}(\%)\end{array}$ & $\mathrm{p}$-value & OR (95\% Cl) \\
\hline $\begin{array}{l}\text { 2282del14 } \\
\text { normal } \\
\text { null }\end{array}$ & $\begin{array}{c}4(92.5 \%) \\
4(7.5 \%)\end{array}$ & $\begin{array}{c}30(90.9 \%) \\
3(9.1 \%)\end{array}$ & $p=0.779$ & $1.22(0.20 \div 7.31)$ \\
\hline $\begin{array}{c}\text { Combined FLG genotype } \\
\text { normal } \\
\text { null }\end{array}$ & $\begin{array}{c}46(85.2 \%) \\
8(14.8 \%)\end{array}$ & $\begin{array}{c}29(87.9 \%) \\
(12.1 \%)\end{array}$ & $p=0.724$ & $1.26(0.30 \div 5.54)$ \\
\hline
\end{tabular}

graphic characteristics between case and control groups were evaluated using the $\chi^{2}$ test or the Fisher exact test as appropriate. The associations of genotypes or alleles with patient groups vs control subjects were determined by computing the odds ratio (OR), its $95 \%$ confidence interval $(95 \% \mathrm{CI})$ and $\mathrm{p}$-values using the logistic regression analysis for crude ORs. The predictive value of risk factors was assessed through analyzing the sensitivity, specificity, and the positive and negative predictive values. Risk factor's interaction was investigated by using logistic regression models for atopic eczema and asthma with interaction terms (SPSS). Statistical significance was set at a $\mathrm{p}$ value $<0.05$. The statistical analyses were carried out using the program package STATISTICA v. 9.0 (StatSoft, Inc., Tulsa, USA) and the SPSS Statistics software package v. 11.1 (SPSS Inc., Chicago, USA).

\section{Results}

Baseline characteristics of patients with eczema and controls are given in Table 1 . There were no significant differences between the cases and the controls in regards to age and gender. The allele and genotype distributions for the FLG mutationsR501X, 2282del14, R2447X and S3247X in the cases and controls are shown in Table 2. The genotype frequencies of all 4 investigated mutations were in agreement with the HardyWeinberg equilibrium in both groups.

An analysis of the combination of all 4 tested FLG mutations revealed a significant association with susceptibility to eczema $(p=0.016)$. In other words, an individual carrying one of these 4 mutations has an approx. 5 times greater chance of having eczema when compared with an individual who does not carry any of these variants. When analyzing distribution of individual variants an association between 2282del14 deletion and eczema was seen, although the statistical significance of this association was borderline. The common R501X variants were not significantly associated with eczema when analyzed individually. Neither R2447X nor S3247X were associated with susceptibility to eczema (Table 2).

Furthermore, there were no significant associations between eczema severity and either the 2282del14 deletion or the combined FLG variants. In our study there were no patients with severe eczema and no significant differences between the patients with mild 
Table 4. Associations between the combined FLG genotype and serum total IgE

\begin{tabular}{|c|c|c|c|c|c|c|}
\hline \multirow[b]{2}{*}{ Genotype } & \multicolumn{3}{|c|}{ Control } & \multicolumn{3}{|c|}{ Eczema } \\
\hline & n (\%) & $\begin{array}{l}\text { serum total lgE } \\
\text { IU/mL, geometric } \\
\text { mean, } 95 \% \mathrm{Cl}\end{array}$ & $\begin{array}{l}\text { student's } \\
\text { t-test }\end{array}$ & $n(\%)$ & $\begin{array}{l}\text { serum total lgE } \\
\text { IU/mL, geometric } \\
\text { mean, } 95 \% \mathrm{Cl}\end{array}$ & $\begin{array}{l}\text { student's } \\
\text { t-test }\end{array}$ \\
\hline $\begin{array}{l}\text { Combined FLG genotype } \\
\text { normal } \\
\text { null }\end{array}$ & $\begin{array}{c}69(97.2) \\
2(2.8)\end{array}$ & $\begin{array}{c}15.30(11.37 \div 19.23) \\
7.39(1.64 \div 13.14)\end{array}$ & $\begin{array}{l}t=0.666 \\
p=0.507\end{array}$ & $\begin{array}{l}75(86.2) \\
12(13.8)\end{array}$ & $\begin{array}{l}28.97(24.47 \div 34.31) \\
40.28(22.94 \div 70.74)\end{array}$ & $\begin{array}{l}t=16.59 \\
p=0.0001\end{array}$ \\
\hline
\end{tabular}

Table 5. Associations between the combined FLG genotype and allergic sensitization and eczema plus asthma

\begin{tabular}{|c|c|c|c|c|c|}
\hline \multirow{2}{*}{ Genotype } & \multirow{2}{*}{ Total n (\%) } & \multicolumn{4}{|c|}{ Combined FLG genotype status } \\
\hline & & FLG normal (\%) & FLG null (\%) & p-value & OR $(95 \% \mathrm{Cl})$ \\
\hline Allergic sensitization & $50 / 158(31.6 \%)$ & $40 / 144(27.7 \%)$ & 10/14 (71.4\%) & $p=0.002$ & $6.50(1.73 \div 26.33)$ \\
\hline Polisensitization (Sepc. IgE > 1) & 23/158 (14.5\%) & $16 / 144(11.1 \%)$ & $7 / 14(50.0 \%)$ & $p=0.001$ & $8.00(2.16 \div 29.98)$ \\
\hline $\begin{array}{l}\text { Allergic sensitization in subjects } \\
\text { with eczema }\end{array}$ & $42 / 87(48.3 \%)$ & $32 / 75(42.6 \%)$ & 10/12 (83.3\%) & $p=0.009$ & $6.71(1.24 \div 47.94)$ \\
\hline $\begin{array}{l}\text { Allergic sensitization in subjects } \\
\text { without eczema }\end{array}$ & $8 / 71(11.3 \%)$ & $8 / 69(11.6 \%)$ & $0 / 2(0 \%)$ & $p=1.000$ & - \\
\hline Eczema plus asthma & 26/158 (16.5\%) & $22 / 144(15.3 \%)$ & 4/14 (28.6\%) & $p=0.042$ & $6.27(0.89 \div 53.56)$ \\
\hline Eczema without asthma & $61 / 158(38.6 \%)$ & $53 / 144(36.8 \%)$ & 8/14 (57.1\%) & $p=0.044$ & $5.20(0.96 \div 37.17)$ \\
\hline $\begin{array}{l}\text { Eczema plus asthma vs eczema } \\
\text { without asthma }\end{array}$ & $42 / 87(48.3 \%)$ & 22/75 (29.3\%) & 4/12 (33.3\%) & $p=0.746$ & $1.20(0.27 \div 5.08)$ \\
\hline
\end{tabular}

Table 6. Associations between FLG mutation 2282del14 and the combined FLG genotype and atopic and non-atopic eczema

\begin{tabular}{|c|c|c|c|c|c|c|c|}
\hline \multirow{2}{*}{ Genotype } & \multirow{2}{*}{ Control n(\%) } & \multicolumn{3}{|c|}{ Atopic eczema } & \multicolumn{3}{|c|}{ Non-atopic eczema } \\
\hline & & $\mathrm{n}(\%)$ & p-value & OR $(95 \% \mathrm{Cl})$ & n (\%) & $p$-value & OR $(95 \% \mathrm{CI})$ \\
\hline $\begin{array}{l}\text { 2282del14 } \\
\text { normal } \\
\text { null }\end{array}$ & $\begin{array}{c}70(98.6 \%) \\
1(1.4 \%)\end{array}$ & $\begin{array}{c}45(90.0 \%) \\
5(10.0 \%)\end{array}$ & $p=0.030$ & $\begin{array}{c}7.78 \\
(0.83 \div 181.9)\end{array}$ & $\begin{array}{c}35(94.6 \%) \\
2(5.4 \%)\end{array}$ & $p=0.230$ & $\begin{array}{c}4.00 \\
(0.27 \div 115.7)\end{array}$ \\
\hline $\begin{array}{l}\text { Combined FLG genotype } \\
\text { normal } \\
\text { null }\end{array}$ & $\begin{array}{c}69(97.2 \%) \\
2(2.8 \%)\end{array}$ & $\begin{array}{l}40(80.0 \%) \\
10(20.0 \%)\end{array}$ & $p=0.002$ & $\begin{array}{c}8.62 \\
(1.64 \div 60.2)\end{array}$ & $\begin{array}{c}35(94.6 \%) \\
2(5.4 \%)\end{array}$ & $p=0.605$ & $\begin{array}{c}1.97 \\
(0.18 \div 20.6)\end{array}$ \\
\hline
\end{tabular}

Table 7. Prevalence and predictive values of risk factors (FLG, allergic sensitization) for eczema

\begin{tabular}{|c|c|c|c|c|c|c|c|c|}
\hline Predictor & $\begin{array}{c}\text { True- } \\
\text { positive }\end{array}$ & $\begin{array}{l}\text { False- } \\
\text { positive }\end{array}$ & $\begin{array}{c}\text { True- } \\
\text { negative }\end{array}$ & $\begin{array}{c}\text { False- } \\
\text { negative }\end{array}$ & $\begin{array}{l}\text { Sensitivity } \\
\%(95 \% \mathrm{Cl})\end{array}$ & $\begin{array}{l}\text { Specificity } \\
\%(95 \% \mathrm{Cl})\end{array}$ & $\begin{array}{c}\text { Positive predicitve } \\
\text { value (PPV) } \\
\%(95 \% \mathrm{Cl})\end{array}$ & $\begin{array}{c}\text { Negative predictive } \\
\text { value (NPV) } \\
\%(95 \% \mathrm{Cl})\end{array}$ \\
\hline FLG mutation & 12 & 2 & 69 & 75 & $\begin{array}{c}13.7 \\
(7.3 \div 22.8)\end{array}$ & $\begin{array}{c}97.1 \\
(90.1 \div 99.5)\end{array}$ & $\begin{array}{c}85.7 \\
(57.1 \div 97.8)\end{array}$ & $\begin{array}{c}47.9 \\
(39.5 \div 56.3)\end{array}$ \\
\hline $\begin{array}{l}\text { Allergic } \\
\text { sensitization }\end{array}$ & 42 & 8 & 63 & 45 & $\begin{array}{c}48.2 \\
(37.4 \div 59.2)\end{array}$ & $\begin{array}{c}88.7 \\
(78.9 \div 94.9)\end{array}$ & $\begin{array}{c}84.0 \\
(70.9 \div 92.8)\end{array}$ & $\begin{array}{c}58.3 \\
(48.4 \div 67.7)\end{array}$ \\
\hline $\begin{array}{l}\text { FLG muatation } \\
\text { and allergic } \\
\text { sensitization }\end{array}$ & 10 & 0 & 60 & 43 & $\begin{array}{c}18.8 \\
(9.45 \div 31.9)\end{array}$ & $\begin{array}{c}100.0 \\
(93.9 \div 100.0)\end{array}$ & $\begin{array}{c}100.0 \\
(68.9 \div 100.0)\end{array}$ & $\begin{array}{c}58.2 \\
(48.1 \div 67.9)\end{array}$ \\
\hline
\end{tabular}

Table 8. Prevalence and predictive values of risk factors (FLG, allergic sensitization) for eczema plus asthma phenotype

\begin{tabular}{|c|c|c|c|c|c|c|c|c|}
\hline Predictor & $\begin{array}{l}\text { True- } \\
\text { positive }\end{array}$ & $\begin{array}{c}\text { False- } \\
\text { positive }\end{array}$ & $\begin{array}{c}\text { True- } \\
\text { negative }\end{array}$ & $\begin{array}{c}\text { False- } \\
\text { negative }\end{array}$ & $\begin{array}{l}\text { Sensitivity } \\
\%(95 \% \mathrm{Cl})\end{array}$ & $\begin{array}{l}\text { Specificity } \\
\%(95 \% \mathrm{Cl})\end{array}$ & $\begin{array}{c}\text { Positive predicitve } \\
\text { value (PPV) } \\
\%(95 \% \mathrm{Cl})\end{array}$ & $\begin{array}{c}\text { Negative predictive } \\
\text { value (NPV) } \\
\%(95 \% \mathrm{Cl})\end{array}$ \\
\hline FLG mutation & 4 & 2 & 69 & 22 & $\begin{array}{c}15.4 \\
(4.4 \div 34.8)\end{array}$ & $\begin{array}{c}97.2 \\
(90.1 \div 99.5)\end{array}$ & $\begin{array}{c}66.6 \\
(22.7 \div 94.7)\end{array}$ & $\begin{array}{c}75.8 \\
(65.7 \div 84.2)\end{array}$ \\
\hline $\begin{array}{l}\text { Allergic } \\
\text { sensitization }\end{array}$ & 15 & 9 & 62 & 11 & $\begin{array}{c}57.7 \\
(36.9 \div 99.6)\end{array}$ & $\begin{array}{c}88.3 \\
(77.3 \div 94.0)\end{array}$ & $\begin{array}{c}62.5 \\
(40.6 \div 81.2)\end{array}$ & $\begin{array}{c}84.9 \\
(74.6 \div 92.2)\end{array}$ \\
\hline $\begin{array}{l}\text { FLG muatation } \\
\text { and allergic } \\
\text { sensitization }\end{array}$ & 3 & 0 & 60 & 10 & $\begin{array}{c}23.1 \\
(5.3 \div 53.8)\end{array}$ & $\begin{array}{c}100.0 \\
(93.9 \div 100.0)\end{array}$ & $\begin{array}{c}100.0 \\
(30.4 \div 100.0)\end{array}$ & $\begin{array}{c}85.7 \\
(75.3 \div 92.9)\end{array}$ \\
\hline
\end{tabular}


Table 9. Interaction between FLG mutation and allergic sensitization in eczema plus asthma phenotype

\begin{tabular}{|c|c|c|c|c|c|}
\hline Risk factors & $\begin{array}{l}\text { Eczma plus asthma } \\
\qquad \mathrm{n}(\%)\end{array}$ & $\begin{array}{l}\text { Control } \\
n(\%)\end{array}$ & $\mathrm{p}$-value & OR $(95 \% \mathrm{Cl})$ & $\operatorname{RR}(95 \% \mathrm{Cl})$ \\
\hline $\begin{array}{l}\text { FLG mutation (-) } \\
\text { Allergic sensitization (-) }\end{array}$ & $\begin{array}{c}10 \\
(38.5 \%)\end{array}$ & $\begin{array}{c}60 \\
(84.5 \%)\end{array}$ & Ref. & 1.00 & 1.00 \\
\hline $\begin{array}{l}\text { FLG mutation (-) } \\
\text { Allergic sensitization (+) }\end{array}$ & $\begin{array}{c}12 \\
(46.2 \%)\end{array}$ & $\begin{array}{c}9 \\
(12.7 \%)\end{array}$ & $p<0.001$ & $\begin{array}{c}8.00 \\
(2.4 \div 27.9)\end{array}$ & $\begin{array}{c}4.00 \\
(1.6 \div 8.0)\end{array}$ \\
\hline $\begin{array}{l}\text { FLG mutation (+) } \\
\text { Allergic sensitization (-) }\end{array}$ & $\begin{array}{c}1 \\
(3.8 \%)\end{array}$ & $\begin{array}{c}2 \\
(2.8 \%)\end{array}$ & $p=0.392$ & $\begin{array}{c}3.00 \\
(0.09 \div 49.6)\end{array}$ & $\begin{array}{c}2.33 \\
(0.11 \div 7.26)\end{array}$ \\
\hline $\begin{array}{l}\text { FLG mutation }(+) \\
\text { Allergic sensitization (+) }\end{array}$ & $\begin{array}{c}3 \\
(11.5 \%)\end{array}$ & $\begin{array}{c}0 \\
(0 \%)\end{array}$ & $p<0.001$ & - & $\begin{array}{c}7.00 \\
(1.86 \div 7.00)\end{array}$ \\
\hline
\end{tabular}

and moderate eczema could be observed in genotype frequencies for either 2282del14 mutation or the combined FLG mutations (Table 3). However, patients who carried at least one risk of FLG mutation alleles displayed a trend of disease onset at an earlier age compared with wildtype genotype (mean age 2.5 and 4.7 months, respectively; $\mathrm{p}=0.045)$.

We also assessed the association between FLG mutations and eczema-associated phenotypes including elevated total IgE level and allergic sensitization. We found a significant difference in total serum IgE levels among genotypes in subjects with eczema ( $p=0.0001)$, whereas such a difference was not present in healthy control ( $\mathrm{p}=0.507)$ (Table 4$)$. We observed a highly significant association of the combined FLG null mutations with allergic sensitization and allergic sensitization with eczema. The association with allergic sensitization was stronger for multiply sensitized children. In contrast, this association was not evident in the absence of eczema (Table 5).

When the atopic and non-atopic eczema groups were analyzed separately, the atopic eczema patients had at least one risk of FLG mutations alleles significantly more frequently than the control group. We noted that the frequency of at least one risk of FLG mutations alleles was significantly increased only in atopic eczema patients when compared to controls ( $\mathrm{p}=0.002$; OR 8.62 (95\% CI $1.64,60.2)$. No significant differences between the patients with non-atopic eczema and the healthy controls could be observed. The non-atopic and atopic eczema groups differ in term of the frequency of the combinations of these FLG mutations, although the statistical significance of this association was borderline $(\mathrm{p}=0.05$; OR 4.37 (95\% CI 0.81, 31.15). Concerning the 2282del14 mutation, a similar trend was observed; children who were carriers of the 2282del14 deletion had an almost 8-fold higher risk of having atopic eczema when compared to controls. No significant association was seen in the case of the non-atopic eczema group. The non-atopic and atopic eczema groups did not differ in term of frequency of this mutation ( $\mathrm{p}=0.607$; OR 1.94 (95\% CI 0.30, 15.50) (Table 6).

We next evaluated the association between the com- bined FLG mutations and the presence of eczema and asthma combination. This analysis revealed that the combined FLG mutations predispose patients to eczema plus asthma, increasing the risk of this complex phenotype more than 6-fold ( $\mathrm{p}=0.043$; OR 6.27 (95\% CI 0.89, 53.56). Independent of asthma, FLG mutations conferred a substantial risk for atopic eczema. In contrast, when we evaluated the FLG mutations as a risk factor for asthma in the subgroup of children with eczema we couldn't find any correlation with the FLG mutations as a significant, independent risk factor of asthma. Additional analysis revealed a significant effect of allergic sensitization on the complex phenotype eczema plus asthma susceptibility ( $\mathrm{p}=0.002$; OR 3.93 (95\% CI 1.52, 10.26) (Table 5).

Further analyses showed that the FLG mutations are a stronger predictor for the development of eczema and eczema plus asthma phenotype with a positive predictive values $85.71 \%$ and $66.67 \%$, respectively. Similarly, allergic sensitization was associated with the very high positive predictive values for eczema and eczema plus asthma, $84.0 \%$ and $62.5 \%$, respectively. Nonetheless, the presence of both risk factors, FLG mutations and allergic sensitization, provided the best combination of diagnostic specificity (100\%) and predicted either eczema or eczema plus asthma phenotype with a positive predictive value of $100 \%$ (Table 7 and 8 ).

Next, we examined the possible interactive effect of FLG mutations and allergic sensitization in relation to complex phenotype eczema plus asthma. We observed that allergic sensitization was associated with 4-fold higher risk for eczema plus asthma phenotype. In contrast, FLG mutations had no additional effect on this phenotype susceptibility in the absence of allergic sensitization. However, the strongest effect was revealed in subjects who carried both risk factors; 7-fold higher risk of having eczema and asthma combination was seen in this high-risk group. As shown in Table 9, relative risks (RRs), odds ratios (ORs) and p values for eczema plus asthma suggested the presence of an interaction, although when modeling interactions, the interaction coefficient was not significant for both risk factors combination ( $\mathrm{p}$ for interaction > 0.05). 


\section{Discussion}

This study is, to our knowledge, the first to investigate the association between the FLG mutations R501X, 2282del14, R2447X and S3247X and susceptibility to and severity of eczema in Polish children younger than 2 years of age. Although the potential role of FLG mutations as a major predisposing factor for atopic eczema has received considerable attention in recent years, to date there were only two studies investigating FLG mutations R501X, 2282del4 in Polish adults and older children. ${ }^{15,16}$ In our results, we found a significant association between the combined genotype of all 4. FLG mutations and the susceptibility to eczema. The frequency of 2282 del14 deletion showed a similar trend, although the statistical significance of this association was borderline. These findings suggest that FLG mutations may contribute to the genetic susceptibility to eczema in Polish children population. However, the frequency of all tested FLG mutations in our population was rather low. In the analysis, heterozygous and homozygous FLG mutation carriers were grouped in one category, as it has been used in the majority of studies. The rationale for statistical analysis using "combined null genotype" is the equivalent effect of FLG null mutations. It has been shown biochemically, both in mice and humans, that distal FLG null mutations are equivalent in term of preventing profilaggrin-to-filaggrin processing and result in a similar reduction or complete absence of filaggrin as well as a similar phenotype and with statistically similar effect. ${ }^{17,18}$ Our results are in agreement with previous studies conducted on the Polish adult and older children population ${ }^{15,16}$ and confirm the previous findings that FLG mutations are strongly associated with atopic eczema. ${ }^{3}$ This highly significant association has been replicated in more than 30 independent studies. ${ }^{4}$ Two recent meta-analyses of this data have estimated the odds ratio (OR) of having atopic dermatitis in association with FLG-null genotype to 4.78 and 3.12. ${ }^{8,9}$ To date, there have been only 2 published studies that did not shown an association between FLG null mutations and atopic eczema. ${ }^{19,20}$

Our observation that eczema patients carrying FLG mutation were younger at the onset of eczema than those without FLG mutations are in agreement with previous studies indicating that FLG mutations have the effect on the age of onset of atopic eczema and can lead to earlyonset that persists well into adulthood. ${ }^{21,22}$ Further observations will be helpful in determining the effect of FLG mutations on the persistence of disease in our population.

Unexpectedly, we are not able to find an association between FLG mutations and eczema severity. An explanation for the lack of this association could be the study design using a general population. Previous studies showing a positive association between FLG null mutations and atopic eczema have focused on moderate-or-severe eczema cases recruited from specialist clinics and on children with eczema as part of atopy-related birth cohort studies. ${ }^{3,10,18,20,22,23}$ It is possible that an association existed in Polish children with moderate-severe atopic eczema but unfortunately most of our participants have mild (62\%) or moderate (38\%) eczema. On the other hand, few studies reported that there was no association between FLG mutations and the severity of atopic eczema like our results. ${ }^{24,25}$

Previous studies have shown that FLG gene mutations increase the risk for atopic eczema, but the data for nonatopic eczema has been scarce. ${ }^{8,10}$ Therefore, in the present study we investigated the association between FLG mutations and allergic sensitization showing that FLG alleles conferred an increased risk for allergic sensitization, which was strongest in children with eczema. We assessed also the distribution of the FLG gene variants in children with atopic eczema and non-atopic eczema. While the two groups did not differ significantly in case of 2282del14 deletion and the differences was borderline for combined FLG mutations, we demonstrated a positive and significant association between either the combined FLG genotype or 2282del14 deletion and eczema only in allergic group. Our results are consistent with studies in other populations showing that FLG null mutations increased the risk of allergic sensitization. . $^{8,10,12,13,21,26}$

Previously established associations between FLG mutations and susceptibility to eczema-associated asthma has been also confirmed in our study. The compound phenotype of asthma in the context of eczema has shown a striking association with FLG null mutations. That is, the combined FLG mutations conferred an approximately 6 -fold increased risk for eczema plus asthma phenotype in our population. This is consistent with studies in the European populations, which have reported that variants in the FLG gene are associated with eczema and concomitant asthma. ${ }^{9-13,26}$

It is worth mentioning that either allergic sensitization or asthma was associated with FLG mutations only in the context of eczema. These results suggest that the presence of an FLG loss-of-function mutation might predispose people to the sequential development of these allergic phenotypes instead of acting as an independent risk factor. Thus, the previous onset of eczema appears to be required for subsequent in the context of "the atopic march". ${ }^{10,12}$ These findings support the theory that FLG mutations lead to a functional epidermal barrier defect and subsequent allergic sensitization. The mechanism leading from skin barrier dysfunction to allergic sensitization may be increased skin permeability to allergens. Recent animal studies support this mechanism by showing an increased uptake of intact allergen through the skin in FLG-deficient mice and resulting increased IgE sensitization and skin inflammation. ${ }^{5,27,28}$ The pathway from FLG defect to airway disease is not yet understood, 
as FLG is not expressed in the respiratory epithelium of the nose or the lower airways. ${ }^{29}$ It is possible that FLG mutations drive allergic disease at distant mucosal site as a systemic, possibly immunological, response to enhanced penetration by antigens through the impaired skin barrier. ${ }^{28}$ Although this molecular pathway is not fully elucidated, former experimental study implicated the $\mathrm{Th}_{17}$ response as a key player between epicutaneous antigen exposure and subsequent airway inflammation. ${ }^{30}$

An association between FLG variants and asthma limited only to asthma with the co-expression of eczema, replicating earlier reports and emphasizing the notion that the FLG deficiency might be a predisposing factor to the particular asthma phenotype occurring in the context of eczema in contrast to the form of asthma not linked with eczema. It is conceivable that this distinct endophenotype of both asthma and eczema is initiated by impaired skin barrier function and thus has a unique pathogenic and prognostic implication. ${ }^{9,31}$

Additionally, our analysis revealed that FLG mutations are not an independent risk factor for asthma in children with eczema. The FLG mutations were a strong predictor for eczema-associated asthma, with high positive predictive values of $66.7 \%$. However, we can see that the combination of FLG mutations and allergic sensitization increases significantly the probability of eczema-associated asthma. In our population $100 \%$ of children with at least one FLG mutation and allergic sensitization had developed eczema-associated asthma up to the age of 4 years. Similarly, our analysis of interactive effect of FLG mutations and allergic sensitization with respect to eczema plus asthma phenotype revealed that children who carried both risk factors had a significantly higher risk of eczema-associated asthma suggesting some possible synergistic interactions. These findings are in accordance with a study conducted in the German Multicentre Allergy Study (MAS) that found a strong synergistic interaction between the FLG-null alleles and early food sensitization in the disease transition from eczema to asthma. ${ }^{11}$

A potential limitation of our study, typical for all casecontrol studies, is a relatively small sample size and, as a consequence, rather low statistical power, which may lead to false negative or fortuitous false positive results. Secondly, an interaction analysis requires a large population; hence, our results should be interpreted carefully. Additionally, rather than fully sequencing FLG to identify target mutations, 4 known mutations were examined. Therefore, the effect of other mutations on the development of or severity of atopic dermatitis and eczema-associated asthma could not be determined.

In conclusion, we provide a significant confirmation of the previously reported association of the FLG mutations with eczema and eczema-associated asthma. Furthermore, we demonstrate that these mutations predispose people to the atopic form of eczema. In spite of the significant effect demonstrated in our study, FLG null mu- tations can only explain a small proportion of the total burden of childhood atopic eczema. Twelve (13.8\%) of 87 atopic eczema cases in our population carry heterozygous genotype for at least one FLG mutations and thus can be attributed to FLG deficiency. The residual $86.2 \%$ of cases remain to be explained by other genetic and environmental factors. However, FLG is the single most significant genetic factor in atopic eczema that has been identified to date, and our findings support the role of the epidermal barrier and filaggrin insufficiency in the pathogenesis of atopic eczema, allergic sensitization and eczema-associated asthma.

\section{References}

1. Schultz Larsen F, Hanifin J. Epidemiology of atopic dermatitis. Immunol Allergy Clin North Am. 2002;22:1-24.

2. Cork MJ, Robinson DA, Vasilopoulos $Y$, et al. New perspectives on epidermal barrier dysfunction in atopic dermatitis: Gene-environment interactions. J Allergy Clin Immunol. 2006;118:3-21.

3. Palmer CNA, Irvine AD, Terron-Kwiatkowski A, et al. Common lossof-function variants of the epidermal barrier protein filaggrin are a major predisposing factor for atopic dermatitis. Nat Genet. 2006;38:441-446.

4. Brown SJ, McLean WH. One remarkable molecule: Filaggrin. J Invest Dermatol. 2012;132:650-654.

5. McAleer MA, Irvine AD. The multifunctional role of filaggrin in allergic skin disease. J Allergy Clin Immunol. 2013;131:280-291.

6. Cookson WO, Ubhi B, Lawrence R, et al. Genetic linkage of childhood atopic dermatitis to psoriasis susceptibility loci. Nat Genet. 2001;27:372-373.

7. Mildner M, Jin J, Eckhart L, et al. Knockdown of filaggrin impairs diffusion barrier function and increases UV sensitivity in a human skin model. J Invest Dermatol. 2010;130:2286-2294.

8. van den Oord RA, Sheikh A. Filaggrin gene defects and risk of developing allergic sensitisation and allergic disorders: Systematic review and meta-analysis. BMJ. 2009;339:b2433.

9. Rodriguez $\mathrm{E}$, Baurecht $\mathrm{H}$, Herberich $\mathrm{E}$, et al. Meta-analysis of filaggrin polymorphisms in eczema and asthma: Robust risk factors in atopic dermatitis. J Allergy Clin Immunol. 2009;123:1361-1370.

10. Marenholz I, Nickel R, Ruschendorf F, et al. Filaggrin loss-of-function mutations predispose to phenotypes involved in the atopic March. J Allergy Clin Immunol. 2006;118:866-871.

11. Marenholz I, Kerscher T, Bauerfeind A, et al. An interaction between filaggrin mutations and early food sensitization improves the prediction oh childhood asthma. J Allergy Clin Immunol. 2009;123: 911-916.

12. Henderson J, Northstone K, Lee SP, et al. The burden of disease associated with filaggrin mutations: A population-based, longitudinal birth cohort study. J Allergy Clin Immunol. 2008;121:872-877.

13. Weidinger $S, O$ 'Sullivan $M$, Illig $T$, et al. Filaggrin mutations, atopic eczema, hay fever, and asthma in children. J Allergy Clin Immunol. 2008;121:1203-1209

14. Hanifin JM, Rajka G. Diagnostic featrures of atopic dermatitis. Acta Derm Venerol Suppl (Stockh). 1980;92:44-47.

15. Lesiak A, Przybyłowska K, Zakrzewski M, et al. Mutacje R501X i 2282del14 w genie filagryny a atopowe zapalenie skóry. Alergia Astma Immunologia. 2010;15:162-169.

16. Ponińska J, Samoliński B, Tomaszewska A, et al. Filaggrin gene defects are independent risk factors for atopic asthma in a Polish population: A Study in ECAP Cohort. PLOS ONE. 2011;6:e16933.

17. Presland RB, Boggess D, Lewis SP, Hull C, Flackman $P$, Sundberg JP. Loss of normal profilaggrin and filaggrin in flaky tail $(\mathrm{ft} / \mathrm{ft})$ mice: An animal model for the filaggrin-deficient skin disease ichthyosis vulgaris. J Invest Dermatol. 2000;115:1072-1081.

18. Sandilands A, Terron-Kwiatkowski A, Hull PR, et al. Comprehensive analysis of the gene encoding filaggrin uncovers prevalent and rare mutation in ichthyosis vulgaris and atopic eczema. Nat Genet. 2007;39:650-654. 
19. Giardina E, Paolillo N, Sinibaldi C, et al. R501X and 2282del4 filaggrin mutations do not confer susceptibility to psoriasis and atopic dermatitis in Italian patients. Dermatology. 2008;216:83-84.

20. Ercan H, Ispir T, Kirac D, et al. Predictors of atopic dermatitis phenotypes and severity: Role of serum immunoglobulins and filaggrin gene mutations R501X. Allergol Immunopathol. 2013;41:86-93.

21. Weidinger S, Rodriguez E, Stahl C, et al. Filaggrin mutations strongly predispose to early-onset and extrinsic atopic dermatitis. J Invest Dermatol. 2007;127:724-726.

22. Barker JN, Palmer CN, Zhao Y, et al. Null mutations in the filaggrin gene (FLG) determine major susceptibility to early-onset atopic dermatitis that persists into adulthood. J Invest Dermatol. 2007;127:564-567.

23. Stemmler S, Parwez Q, Petrasch-Parwez E, Epplen JT, Hoffjan S. Two common loss-of-function mutations within the filaggrin gene predispose for early onset of atopic dermatitis. J Invest Dermatol. 2007;127:722-724.

24. Ho-Sung $\mathrm{Y}$, Mi-Jin $\mathrm{K}$, Young-Ho J, et al. Mutations at filaggrin are predisposing factor in Korean children with atopic dermatitis. Allergy Asthma Immunol Res. 2013;5:211-215.

25. Zhang H, Guo Y, Wang W, Shi M, Chen X, Yao Z. Mutations in the filaggrin gene in Han Chinese patients with atopic dermatitis. Allergy. 2011;66:420-427.

26. Bořnnelykke $\mathrm{K}$, Pipper $\mathrm{CB}$, Tavendale R, Palmer CNA, Bisgaard $\mathrm{H}$. Filaggrin gene variants and atopic diseases in early childhood assessed longitudinally from birth. Pediatr Allergy Immunol. 2010;21:954-961.

27. Fallon PG, Sasaki T, Sandilands A, et al. A homozygous frameshift mutation in the mouse Flg gene facilitates enhanced percutaneous allergen priming. Nat Genet. 2009;41:602-608.

28. De Benedetto A, Kubo A, Beck LA. Skin barrier disruption: A requirement for allergen sensitization? J Invest Dermatol. 2008;132: 949-963.

29. Ying $\mathrm{S}$, Meng $\mathrm{Q}$, Corrigan $\mathrm{CJ}$, Lee TH. Lack of filaggrin expression in the human bronchial mucosa. J Allergy Clin Immunol. 2006;118:1386-1388.

30. He R, Oyoshi MK, Jin H, Geha RS. Epicutaneous antigen exposure induces a Th17 response that drives airway inflammation after inhalation challenge. Proc Natl Acad Sci. 2007;104:15817-15822.

31. Bisgaard $\mathrm{H}$, Bonnelykke K. Long-term studies of the natural history of asthma in childhood. J Allergy Clin Immunol. 2010;126:187-119. 